\title{
МЕТАБОЛИТЫ ОКСИДА АЗОТА В ТКАНЯХ, СЫВОРОТКЕ КРОВИ, МОНОНУКЛЕАРНЫХ И МЕЗЕНХИМАЛЬНЫХ СТВОЛОВЫХ КЛЕТКАХ
}

\author{
() Чеботарёва А.А. ${ }^{l}$, Комаревцева И.А. ${ }^{2}$, Юсур Р.М.С. ${ }^{2}$, Черных Ю.А. ${ }^{2}$, Вишницкая И.А. ${ }^{2}$, \\ Комаревцева Е.В. ${ }^{2}$, Постернак Д.Г. ${ }^{2}$, Серегина Н.М. ${ }^{2}$, Журба А.А. ${ }^{2}$, Морару-Бурлеску Р.П. ${ }^{2}$, \\ Чередниченко Р.В. ${ }^{2}$, Тертычная-Телюк С.В. ${ }^{2}$, Яковлева Т.П. ${ }^{2}$, Кравцова Ю.В. ${ }^{2}$, Симиненко К.А. ${ }^{2}$
}

\author{
${ }^{1}$ Кафедра педиатрии Курского государственного медицинского университета, Курск; \\ ${ }^{2}$ кафедра медицинской химии \\ Луганского государственного медицинского университета, Рубежное, Украина \\ E-mail: chebotareva_alisa@mail.ru
}

\begin{abstract}
Радикал оксида азота - важный медиатор в физиологических и патофизиологических процессах. Радикал NO•короткоживущий и быстро метаболизирующийся в стабильные конечные продукты нитрит и нитрат. Суммарный показатель (нитрит и нитрат) - стабильный конечный продукт оксида азота. В биологических жидкостях организма, включая плазму, большинство нитрита конвертируется в нитрат. Для определения нитритов используют диазотирование на основе реакции Грисса, но нитраты при этом не регистрируются. Поэтому нитраты должны быть восстановлены до нитритов с последующим диазотированием. Таким образом, можно получить суммарное значение $\mathrm{NO}_{2}^{-}+\mathrm{NO}_{3}{ }^{-}{ }^{-}$ пробе. Для проведения данного анализа мы разработали методику, позволяющую определять содержание нитрит- и нитрат-ионов в одной и той же пробе. $\mathrm{NO}_{3}{ }^{-}+\mathrm{NO}_{2}{ }^{-}\left(\mathrm{NO}_{\mathrm{x}}\right)$ мы определяли как $\mathrm{NO}_{2}{ }^{-}$после химической конвертации $\mathrm{NO}_{3}{ }^{-}$ в $\mathrm{NO}_{2}^{-}$спектрофотометрически с использованием реактива Грисса. Разработанная нами методика, как показали наши исследования, адекватна для изучения метаболизма оксида азота в клинике и эксперименте.
\end{abstract}

Ключевые слова: оксид азота, почки, сыворотка крови, хронический алкоголизм, гипертоническая болезнь, мононуклеары, мезенхимальные стволовые клетки.

\section{METABOLITES OF NITRIC OXIDE IN TISSUES, BLOOD PLASMA, MONONUCLEAR AND MESENCHIMAL STEM CELLS}

Chebotareva A.A. , Komarevtseva I.A. ${ }^{2}$, Usuf R.M.S. ${ }^{2}$, Chernykh Yu.A. ${ }^{2}$, Vishnitskaya I.A. ${ }^{2}$, Komarevtseva K.V. ${ }^{2}$, Posternak D.G. ${ }^{2}$, Seregina N.M. ${ }^{2}$, Zhurba A.A. ${ }^{2}$, Moraru-Burlesku R.P. ${ }^{2}$, Cherednichenko R.V. ${ }^{2}$, Tertychnaya-Teliuk S.V. ${ }^{2}$, Yakovleva T.P. ${ }^{2}$, Kravtsova Yu.V. ${ }^{2}$, Siminenko K.A. ${ }^{2}$

${ }^{1}$ Department of Pediatrics of Kursk State Medical University, Kursk;

${ }^{2}$ Department of Medical Chemistry of Lugansk State Medical University, Rubezhnoe, Ukraine

Nitric oxide radical (NO•) is an important mediator of both physiological and pathophysiological processes. The NO• radical is rapidly metabolized into the stable end-products - nitrite and nitrate. $\mathrm{NO}_{\mathrm{x}}$ (nitrate and nitrite) is a stable end product of nitric oxide (NO). In most body fluids, including plasma, most of nitrite is converted into nitrate; thus, determination of nitrite alone is meaningless. The most commonly used nitrite assay is based on the Griess diazotization reaction, which is specific for nitrite and does not detect nitrate. Therefore, nitrate in samples must first be reduced to nitrite; subsequent nitrite determination, thus, yields the total nitrite + nitrate concentration of the sample. $\mathrm{NO}_{3}^{-}$plus $\mathrm{NO}_{2}^{-}\left(\mathrm{NO}_{\mathrm{x}}\right)$ was measured as $\mathrm{NO}_{2}^{-}$after enzymatic conversion of $\mathrm{NO}_{3}{ }^{-}$to $\mathrm{NO}_{2}^{-}$. After the conversion, the spectrophotometric measurement of nitrite is accomplished by using the Griess Reaction. Clearly, the real value of determining NO• or its metabolites - nitrite and nitrate in clinical practice still need to be proved.

Keywords: nitrogen oxide, kidneys, blood serum, chronic alcoholism, hypertension, mononuclear cells, mesenchymal stem cells.

Оксид азота (NO), синтезируемый из L-аргинина синтазами NO, является маленькой, липофильной, диффундирующей, очень реактивной молекулой с дихотомическими регуляторными ролями во многих биологических процессах при физиологических и патологических состояниях $[5,8]$. NO является промотором апоптоза (проапоптоз) в одних клетках и ингибитором апоптоза (антиапоптоз) в других клетках [3, 4, 5]. Такая бифункциональность оксида азота по отношению к апоптозу - результат его разнообразного взаимодействия с другими молекулами - металлами, тиолами, тирозином и активными формами кислорода. Длительная оверпродукция NO действует как проапоптотический модулятор, активизируя протеазы семейства каспазы через выделение митохондриального цитохрома С в цитозоль, регулирование p53 экспрессии и изменения в экспрессии апоптоз-ассоциированных белков, включая семейство Bcl-2. Однако низкие или физиологические концентрации NO оберегают клетки от апоптоза $[3,4,6]$.

В связи с этим мы решили проанализировать на обширном клиническом и экспериментальном материале уровень метаболитов оксида азота 
$\left(\mathrm{NO}_{x}\right)$ в тканях почек, мочевого пузыря, предстательной железы, кожи, в сыворотке крови больных хроническим алкоголизмом, гипертонической болезнью, в мононуклеарах, мезенхимальных стволовых клетках.

\section{МАТЕРИАЛЫ И МЕТОДЫ ИССЛЕДОВАНИЯ}

Всего в процессе работы мы обследовали 121 больного заболеваниями почек, 169 больных раком мочевого пузыря, 78 больных заболеваниями предстательной железы, 114 больных гипертонической болезнью, 126 больных хроническим алкоголизмом, 112 больных хирургической патологией, 56 здоровых доноров. У экспериментальных животных предметом исследования были ткани кожи, почек, предстательной железы, сыворотка крови, мононуклеарные клетки, мезенхимальные стволовые клетки (всего - 142 крысы).

Для проведения анализа метаболитов оксида азота мы разработали методику, позволяющую определять содержание нитрит- и нитрат-ионов в одной и той же пробе [4].

Для определения нитритов использовали диазотирование на основе реакции Грисса. Нитраты восстанавливали до нитритов с последующим диазотированием. Таким образом, получали суммарное значение $\mathrm{NO}_{2}^{-}+\mathrm{NO}_{3}^{-}$в пробе. Нитриты определяли спектрофотометрически.

Все полученные результаты обрабатывались статистически на персональном компьютере «Fujisu-Siemens» (ФРГ) «Pentium Dual-Core» c помощью пакетов статистических программ «Excel» и «Start Graf».

\section{РЕЗУЛЬТАТЫ ИССЛЕДОВАНИЯ И ИХ ОБСУЖДЕНИЕ}

Оксид азота синтезируется из гуанидинового атома азота L-аргинина синтазой оксида азота, которая присоединяет молекулярный кислород к конечному атому азота в гуанидиновой группе L-аргинина [8]. Синтаза оксида азота также продуцирует неактивный конечный продукт L-цитруллин, который является маркером активности синтазы оксида азота $[5,8]$.

Оксид азота необратимо инактивируется реакцией с гемоглобином (оксигенированной и деокигенированной формами) в просвете кровеносного сосуда, супероксидным радикалом в стенке кровеносного сосуда $[10,11]$ или кислородом в свободном растворе [8]. Реакция оксида азота с кислородом сопровождается образованием стабильных конечных продуктов - нитрита и нитрата, которые являются косвенными маркерами концентрации оксида азота в организме $[5,8]$.

Термином «оксид азота» обозначается восстановленная форма моноокиси азота (NO) с периодом полураспада от 2 до 30 с. Его стабильными конечными метаболитами являются нитриты $\left(\mathrm{NO}_{2}^{-}\right)$и нитраты $\left(\mathrm{NO}_{3}^{-}\right)$.

При определении нитрита используется фотометрический метод [2, 3]. Определение нитрита и нитрата, стабильных конечных продуктов оксида азота в крови и других биологических жидкостях производят различными методами. Тотальное определение содержания нитрита и нитрата в плазме крови проводится фотометрическим методом, однако предварительно превращают нитраты в нитриты с помощью покрытой медью кадмиевой колонки [7] или редуктазы [12]. Все методы определения оксида азота можно разделить на две группы: методы выделения NO в «режиме реального времени» и методы выделения стойких метаболитов $\mathrm{NO}\left(\mathrm{NO}_{2}^{-} \backslash \mathrm{NO}_{3}{ }^{-}\right)$.

Методы первой группы позволяют зарегистрировать содержание NO в жизнеспособном биологическом материале: эксплантантах ткани, биопсиях или изолированных клетках [9]. К таким методам относятся электрохимические, хемилюминесцентные (реакция NO с озоном) [9], спектрофотометрические (реакция NO c оксигемоглобином) [2]. В последнее время для определения нитратов и нитритов в биологических жидкостях используются высокоэффективная хроматография и капиллярный электрофорез.

Преимущество этих методов заключается в том, что возможно определение фактического NO. Недостатки этих методов - техническая сложность и их эффективность только для жизнеспособных биологических препаратов. Соответственно, эти методы не подходят для биологических жидкостей, лишенных клеток. Кроме того, использование этих методов в условиях in vivo достаточно осложнено (за исключением электрохимических датчиков).

Спектрофотометрические методы второй группы позволяют определить метаболиты оксида азота $\left(\mathrm{NO}_{2}^{-} \backslash \mathrm{NO}_{3}^{-}\right)$в гомогенате, плазме, моче.

Для определения нитритов используют диазотирование на основе реакции Грисса, но нитраты при этом не регистрируются. Поэтому нитраты должны быть восстановлены до нитритов с последующим диазотированием [2, 3]. Таким образом, можно получить суммарное значение $\mathrm{NO}_{2}^{-}+\mathrm{NO}_{3}^{-}$в пробе. Для проведения 
данного анализа мы разработали методику, позволяющую определять содержание нитрит- и нитрат-ионов в одной и той же пробе [4].

Определение метаболитов оксида азота в сыворотке крови.

Перед анализом на нитриты и нитраты в сыворотке крови проводили осаждение белков смесью 0,5 н раствор $\mathrm{KOH}$ и $5 \%$ раствора $\mathrm{ZnSO}_{4}$ в объемном соотношении 2:5. В пробу добавляли 1 мл реактива Грисса при $\mathrm{t}=5^{\circ} \mathrm{C}$, пробирка интенсивно встряхивалась и через 15 минут развивалась окраска. Далее проводилось спектрофотометрирование при $\lambda=540$ нм на СФ46 , контролем служил дистиллят.

Поскольку реакция диазотирования является специфической только на нитриты, то для определения нитратов проводили их предварительное восстановление. В пробирку к 1 мл сыворотки добавляли 0,3 г «сухого восстановителя» и приливали 1 мл 12\% раствора уксусной кислоты. Процесс восстановления происходил одновременно при $\mathrm{t}=5^{\circ} \mathrm{C}$. Через 10 минут пробирки центрифугировали, отбирали супернатант и проводили спектрофотометрирование при $\lambda=540$ нм против «холостой пробы» (обработанной аналогично).

Определение метаболитов оксида азота в мононуклеарах и мезенхимальных стволовых клетках.

Донорскую кровь предварительно разводили физиологическим раствором в соотношении 1:2 и в количестве 5 мл наслаивали на 2 мл раствора фиколл - верографин $(\rho=1,077)$. Пробы центрифугировали 30 минут при $400 \mathrm{~g}$ и полученные клетки дважды отмывали раствором Хенкса (НИИ полиомиелита и вирусных энцефалитов АМН РФ, г. Москва). Мононуклеарные клетки ресуспензировали в среде Игла МЕМ (производство НИИ полиомиелита и вирусных энцефалитов АМН РФ, г. Москва) с добавлением $10 \%$ эмбриональной телячьей сыворотки (ООО БиолоТ, г. СанктПетербург, сертификат качества № 08-01) и антибиотиков. Культивировали в количестве $2 \cdot 10^{6}$ в 1 мл питательной среды в течение 24 и 48 часов. Количество клеток в пробе подсчитывали в камере Горяева. Жизнеспособность клеток в культуре (свыше $96 \%$ ) определяли путем окрашивания клеток $0,2 \%$ раствором трипанового синего.

Костный мозг получали из бедренных, большеберцовых и плечевых костей. Клетки костного мозга вымывали из полости кости 3 мл питательной среды Игла МЕМ в стерильную пробирку, мезенхимальные стволовые клетки стромы (МСК) отделяли от гемопоэтических стволовых клеток путем ресуспензирования, фильтровали через капроновую сеточку, подсчитывали количество жизнеспособных клеток с помощью трипанового синего. Кроме того, разделение достигалось и за счет адгезии к культуральному пластику. Конечную концентрацию жизнеспособных клеток доводили до $5 \times 10^{4}$ в мл и помещали в пластиковые одноразовые флаконы, площадью $25 \mathrm{~cm}^{2}$. Культивирование клеток проводили в среде Игла MEM, обогащенной L-глутамином, 10\% эмбриональной телячьей сывороткой и с добавлением антибиотиков в течение 12 дней со сменой $1 / 2$ среды каждые пять суток. При достижении 80-90\% монослоя в островках клеток первичной культуры или последующих субкультурах МСК проводили их пассирование. При этом использовали 20 мМ фосфатный буфер, раствор 0,05\% трипсина и раствор Версена (производство НИИ полиомиелита и вирусных энцефалитов АМН РФ, г. Москва). Плотность посадки клеток составляла 2000 кл/см². Культивирование в стандартных условиях проводили при температуре $37^{\circ} \mathrm{C}$ в атмосфере $5 \%$ $\mathrm{CO}_{2}$ в HF151UV $\mathrm{CO}_{2}$ - инкубаторе в условиях насыщенной влажности.

После культивирования мононуклеарные клетки отмывали в $\mathrm{PBS}$ и гомогенизировали с использованием гомогенизатора с тефлоновым пестиком, зазор 0,4-0,8 мм, рабочий объем 50 мл. Гомогенат клеток готовили в сахарозной среде выделения (0,25 M сахарозы, 1мМ ЭДТА), конечное разведение гомогената 1:9 (объем пробы 1 мл). МСК предварительно снимали со стекла с помощью $0,05 \%$ раствора трипсина и 0,02\% раствора Версена в равных пропорциях. Далее проводили диализ 1 мл гомогената в течение 1,5-2 часов против 5 мл дистиллированной воды. После его окончания отбирали и измеряли объем диализата и проводили осаждение белков смесью 0,5 М КОН и $5 \% \mathrm{ZnSO}_{4}$ в объемном соотношении 2:5. Для определения нитритов из общего объема диализата отбирали 1 мл, а для нитратов - 0,5 мл. Содержание нитритов определяли с помощью реактива Грисса. В пробу с объемом 1 мл добавляли 0,1 мл реактива Грисса, пробирки интенсивно встряхивали в течение 2 минут и оставляли при $\mathrm{t}=5^{\circ} \mathrm{C}$ на 15 мин (в пробах развивалась розовая окраска). Измерение оптической плотности проводили на СФ-46 при $\lambda=$ 540 нм, в качестве контроля использовали дистил-лированную воду. Для определения нитрат-анионов их предварительно восстанавливали с помощью «сухого восстановителя». В пробирку к 0,5 мл диализата добавляли 0,03 г восстановителя, 0,5 мл 12\% $\mathrm{CH}_{3} \mathrm{COOH}$ и 0,1 мл реактива Грисса, пробирку встряхивали в течение 
2 минут. Процесс восстановления и диазотирования происходил одновременно при $\mathrm{t}=5^{\circ} \mathrm{C}$. Через 10 мин пробирки центрифугировали при $4000 \mathrm{~g} 5$ минут, отбирали супернатант и проводили измерение при $\lambda=540$ нм против «холостой пробы» $(0,5$ мЛ дистиллированной воды, 0,5 мл $12 \% \mathrm{CH}_{3} \mathrm{COOH}$ и 0,1 мл реактива Грисса).

Определение метаболитов оксида азота в тканях.

Фрагменты исследуемых тканей измельчали и гомогенизировали с использованием гомогенизатора с тефлоновым пестиком, зазор 0,4-0,8 мм, рабочий объем 50 мл. Гомогенат ткани готовили в сахарозной среде выделения $(0,25 \mathrm{M}$ сахарозы, 1м М ЭДТА), конечное разведение гомогената 1:9. Далее проводили диализ в течение 1,5-2 часов против дистиллята. После его окончания отбирали и измеряли объем диализата и проводили осаждение белков смесью $0,5 \mathrm{H} \mathrm{КОН} \mathrm{и}$ $5 \% \mathrm{ZnSO}_{4}$ в объемном соотношении 2:5. Для определения нитритов из общего объема диализата отбирали 10 мл, а для нитратов - 5 мл. Содержание нитритов определяли с помощью реактива Грисса. В пробу с объемом 10 мл добавляли 1 мл реактива Грисса при $\mathrm{t}=5^{\circ} \mathrm{C}$, пробирки интенсивно встряхивали в течение 2 минут, через 15 мин в пробах развивалась окраска. Далее проводили спектрофотометрирование при $\lambda=540$ нм на СФ-46, контролем служил дистиллят [1].

В пробирку к 5 мл диализата добавляли 0,3 г «сухого восстановителя», приливали 5 мл 12\% $\mathrm{CH}_{3} \mathrm{COOH}$ и 1 мл реактива Грисса, пробирку встряхивали в течение 2 минут. Процесс восстановления и диазотирования происходил одновременно при $\mathrm{t}=5^{\circ} \mathrm{C}$. Через 10 мин пробирки центрифугировали при $4000 \mathrm{~g} 5$ минут, затем отбирали супернатант и проводили спектрофотометрирование при $\lambda=540$ нм против «холостой пробы» (обработанной аналогично, но без пробы).

Содержание нитрит- и нитрат-ионов (мг/кг) рассчитывали по формуле, используя концентрацию нитрит- и нитрат-ионов (мг), найденных по калибровочным кривым для рабочих растворов стандарта нитрита натрия и нитрата калия.
Концентрации стабильных метаболитов оксида азота рассчитывали по формуле:

$$
\begin{aligned}
& \mathrm{NO}_{2}^{-}=\mathrm{B} \bullet \mathrm{X}_{1} / \mathrm{A} \bullet \mathrm{X}_{2} \\
& \mathrm{NO}_{\mathrm{x}}=\mathrm{B} \bullet \mathrm{X}_{1} / \mathrm{A} \bullet \mathrm{X}_{2},
\end{aligned}
$$

$\mathrm{B}$ - количество нитрит - анионов $\mathrm{NO}_{2}^{-}$( или $\mathrm{NO}_{\mathrm{x}}^{-}$- анионов, полученных в результате реакции восстановления и диазотирования), найденное по калибровочной кривой, мг;

А - навеска ткани, кг; для сыворотки крови объем пробы в мл;

$\mathrm{X}_{1}$ - общий объем диализата, мл;

$\mathrm{X}_{2}$ - объем пробы для анализа, мл;

$\mathrm{NO}_{\mathrm{x}}$ - сумма ионов $\mathrm{NO}_{3}{ }^{-}$и $\mathrm{NO}_{2}{ }^{-}$, мг/кг; или в $\mu \mathrm{M}$ для сыворотки и клеток, полученная в результате реакции восстановления и диазотирования.

Для определения отдельного содержания нитрат-ионов из суммы нитрат- и нитрит-ионов $\left(\mathrm{NO}_{x}\right)$ вычитают количество нитрит-ионов, рассчитанных по формуле. Расчет нитрат-ионов (мг/кг) производят по формуле:

$$
\mathrm{NO}_{3}{ }^{-}=\mathrm{NO}_{\mathrm{x}}-\mathrm{B} \bullet 1,3, \quad \text { где }
$$

$\mathrm{NO}_{x}$ - сумма ионов $\mathrm{NO}_{3}{ }^{-}$и $\mathrm{NO}_{2}^{-}$, мг/кг; или в $\mu \mathrm{M}$ для сыворотки и клеток;

$\mathrm{B}$ - количество $\mathrm{NO}_{2}^{-}$, мг/кг; или в $\mu \mathrm{M}$ для сыворотки и клеток крови;

1,3 - коэффициент пересчета нитрит-ионов в нитрат-ионы.

Содержание стабильных метаболитов оксида азота выражали в мкг/мг белка в тканях, мкмоль/л в сыворотке крови и клетках крови и костного мозга.

В таблицах 1-4 представлены результаты определения метаболитов оксида азота в тканях почек, мочевого пузыря, предстательной железы, кожи, в сыворотке крови больных хроническим алкоголизмом, гипертонической болезнью, в мононуклеарах, мезенхимальных стволовых клетках.

На основании проведенных исследований можно сделать следующие выводы:

Для проведения анализа метаболитов оксида азота мы разработали методику, позволяющую определять содержание нитрит- и нитрат-ионов в одной и той же пробе.

Для определения нитритов использовали диазотирование на основе реакции Грисса. Нитраты восстанавливали до нитритов с последующим диазотированием. Таким образом, получали суммарное значение $\mathrm{NO}_{2}{ }^{-}+\mathrm{NO}_{3}{ }^{-}$в пробе. Нитриты определяли спектрофотометрически. 
Таблица 1

Содержание метаболитов оксида азота в гомогенатах тканей почек, мочевого пузыря и простаты у больных урологической патологией

\begin{tabular}{|c|c|c|c|c|c|c|}
\hline Клинические группы & \multicolumn{2}{|c|}{$\mathrm{NO}_{3}^{-}(\mu \Gamma / \Gamma)$} & \multicolumn{2}{|c|}{$\mathrm{NO}_{2}^{-}(\mu \Gamma / \Gamma)$} & \multicolumn{2}{|c|}{$\mathrm{NO}_{\mathrm{x}}(\mu \Gamma / \Gamma)$} \\
\hline Паренхима почки & \multicolumn{2}{|c|}{$26,8 \pm 4,2$} & \multicolumn{2}{|c|}{$2,0 \pm 0,07$} & \multicolumn{2}{|c|}{$28,8 \pm 4,0$} \\
\hline $\begin{array}{c}\text { Мочекаменная болезнь } \\
\text { почек }\end{array}$ & \multicolumn{2}{|c|}{$16,3 \pm 3,1$} & \multicolumn{2}{|c|}{$0,77 \pm 0,009$} & \multicolumn{2}{|c|}{$17,7 \pm 2,1$} \\
\hline Пионефроз почки & \multicolumn{2}{|c|}{$8,4 \pm 1,4$} & \multicolumn{2}{|c|}{$0,14 \pm 0,001$} & \multicolumn{2}{|c|}{$8,54 \pm 1,2$} \\
\hline \multirow{2}{*}{$\begin{array}{c}\text { Ангиомиолипоматоз } \\
\text { почки }\end{array}$} & узел & $\begin{array}{c}\text { окруж. } \\
\text { ткань }\end{array}$ & узел & $\begin{array}{c}\text { окруж. } \\
\text { ткань }\end{array}$ & узел & $\begin{array}{c}\text { окруж. } \\
\text { ткань }\end{array}$ \\
\hline & $20,3 \pm 3,8$ & $26,4 \pm 5,1$ & $1,35 \pm 0,04$ & $2,0 \pm 0,05$ & $21,65 \pm 4,8$ & $28,4 \pm 5,2$ \\
\hline \multirow{2}{*}{ Мультикистоз почки } & узел & $\begin{array}{c}\text { окруж. } \\
\text { ткань }\end{array}$ & узел & $\begin{array}{c}\text { окруж. } \\
\text { ткань }\end{array}$ & узел & $\begin{array}{c}\text { окруж. } \\
\text { ткань }\end{array}$ \\
\hline & $18,6 \pm 3,7$ & $24,5 \pm 5,2$ & $1,2 \pm 0,006$ & $1,7 \pm 0,009$ & $19,8 \pm 4,2$ & $26,2 \pm 4,6$ \\
\hline Рак почки & опухоль & $\begin{array}{c}\text { окруж. } \\
\text { ткань }\end{array}$ & опухоль & $\begin{array}{c}\text { окруж. } \\
\text { ткань }\end{array}$ & опухоль & $\begin{array}{c}\text { окруж. } \\
\text { ткань }\end{array}$ \\
\hline $\mathrm{T}_{2} \mathrm{~N}_{0} \mathrm{M}_{0}$ & $32,6 \pm 5,8$ & $19,3 \pm 3,7$ & $2,64 \pm 0,1$ & $1,49 \pm 0,06$ & $35,2 \pm 5,9$ & $21,9 \pm 4,2$ \\
\hline $\mathrm{T}_{3} \mathrm{~N}_{0} \mathrm{M}_{0}$ & $15,4 \pm 3,9$ & $13,4 \pm 3,1$ & $1,29 \pm 0,07$ & $1,08 \pm 0,01$ & $16,6 \pm 4,6$ & $14,6 \pm 3,8$ \\
\hline $\mathrm{T}_{3} \mathrm{~N}_{0} \mathrm{M}_{1}$ & $25,2 \pm 4,5$ & $20,7 \pm 3,9$ & $1,94 \pm 0,05$ & $1,67 \pm 0,07$ & $27,1 \pm 5,4$ & $22,6 \pm 4,3$ \\
\hline Рак мочевого пузыря & опухоль & $\begin{array}{c}\text { окруж. } \\
\text { ткань }\end{array}$ & опухоль & $\begin{array}{c}\text { окруж. } \\
\text { ткань }\end{array}$ & опухоль & $\begin{array}{c}\text { окруж. } \\
\text { ткань }\end{array}$ \\
\hline $\mathrm{T}_{2} \mathrm{~N}_{0} \mathrm{M}_{0}$ & $38,6 \pm 6,4$ & $25,3 \pm 4,6$ & $3,15 \pm 0,2$ & $1,8 \pm 0,007$ & $41,8 \pm 6,3$ & $27,1 \pm 4,5$ \\
\hline $\mathrm{T}_{36} \mathrm{~N}_{0} \mathrm{M}_{0}$ & $16,4 \pm 3,4$ & $24,7 \pm 3,9$ & $1,02 \pm 0,008$ & $1,6 \pm 0,009$ & $17,4 \pm 3,1$ & $26,3 \pm 3,8$ \\
\hline \multirow{2}{*}{$\begin{array}{c}\text { Доброкачественная } \\
\text { гиперплазия простаты }\end{array}$} & узел & $\begin{array}{c}\text { окруж. } \\
\text { ткань }\end{array}$ & узел & $\begin{array}{c}\text { окруж. } \\
\text { ткань }\end{array}$ & узел & $\begin{array}{c}\text { окруж. } \\
\text { ткань }\end{array}$ \\
\hline & $14,8 \pm 2,4$ & $24,5 \pm 4,8$ & $1,15 \pm 0,007$ & $1,9 \pm 0,01$ & $16,0 \pm 3,4$ & $26,4 \pm 3,5$ \\
\hline \multirow[t]{2}{*}{ Рак простаты } & опухоль & $\begin{array}{c}\text { окруж. } \\
\text { ткань }\end{array}$ & опухоль & $\begin{array}{c}\text { окруж. } \\
\text { ткань }\end{array}$ & опухоль & $\begin{array}{c}\text { окруж. } \\
\text { ткань }\end{array}$ \\
\hline & $62,4 \pm 8,9$ & $43,8 \pm 7,4$ & $4,55 \pm 0,3$ & $3,9 \pm 0,2$ & $66,9 \pm 9,1$ & $47,7 \pm 7,8$ \\
\hline
\end{tabular}

Таблица 2

Содержание стабильных метаболитов оксида азота $\left(\mathrm{NO}_{\mathrm{x}}, \mathrm{NO}_{3}{ }^{-}, \mathrm{NO}_{2}{ }^{-}\right)$в клетках почек при «глицерольной» модели острой почечной недостаточности (ОПН)

\begin{tabular}{|l|c|c|c|}
\hline \multicolumn{1}{|c|}{ Группы } & $\begin{array}{c}\mathrm{NO}_{\mathbf{x}} \\
\text { мкг/мг белка }\end{array}$ & $\begin{array}{c}\mathrm{NO}_{3}^{-} \\
\text {мкг/мг белка }\end{array}$ & $\begin{array}{c}\mathrm{NO}_{2}^{-} \\
\text {мкг/мг белка }\end{array}$ \\
\hline Контроль & $3,32 \pm 0,16$ & $3,08 \pm 0,17$ & $0,14 \pm 0,01$ \\
\hline ОПН, 1 сутки & $6,61 \pm 1,00^{*}$ & $6,49 \pm 0,95^{*}$ & $0,12 \pm 0,01$ \\
\hline ОПН, 2 сутки & $7,97 \pm 0,68^{*}$ & $7,85 \pm 0,71^{*}$ & $0,12 \pm 0,01$ \\
\hline ОПН, 3 сутки & $7,07 \pm 0,98^{*}$ & $6,96 \pm 0,85^{*}$ & $0,11 \pm 0,02^{*}$ \\
\hline
\end{tabular}

Примечание: * - различия достоверны относительно контроля, $\mathrm{p}<0,05$.

Таблица 3

Содержание метаболитов оксида азота в мононуклеарных, мезенхимальных стволовых клетках, сыворотке крови

\begin{tabular}{|c|c|c|}
\hline Группы наблюдения & $\mathrm{NO}_{\mathrm{x}}$ & $\mathrm{NO}_{2}{ }^{-}$ \\
\hline $\begin{array}{c}\text { МНК, 24 часа / 48 часов культивирования, } \\
\text { (нмоль/мл на 2 } 10^{6} \text { клеток) }\end{array}$ & $\begin{array}{c}356,1 \pm 21 / 395,4 \pm 16 \text { нмоль/мл } \\
\text { на } 2 \times 10^{6} \text { клеток }\end{array}$ & $\begin{array}{c}21,3 \pm 2,3 / 26,3 \pm 1,2 \text { нмоль/мл } \\
\text { на 2 } 210^{6} \text { клеток }\end{array}$ \\
\hline $\begin{array}{c}\text { МСК, 24 часа / 48 часов культивирования } \\
\text { (нмоль/мл на } 2 \times 10^{6} \text { клеток) }\end{array}$ & $\begin{array}{c}123,4 \pm 7,2 / 127,4 \pm 8,4 \text { нмоль/мл } \\
\text { на } 2 \times 10^{6} \text { клеток }\end{array}$ & $\begin{array}{c}11,5 \pm 1,1 / 16,5 \pm 0,9 \text { нмоль/мл } \\
\text { на } 2 \times 10^{6} \text { клеток }\end{array}$ \\
\hline 3доровые доноры (сыворотка крови) & $24,0 \pm 4,72$ мкмоль/л & $3,2 \pm 0,3$ мкмоль/л \\
\hline $\begin{array}{c}\text { Больные хроническим алкоголизмом } \\
\text { (сыворотка крови) }\end{array}$ & $46,3 \pm 5,9$ мкмоль/л & $6,4 \pm 1,2$ мкмоль/л \\
\hline $\begin{array}{c}\text { Больные гипертонической болезнью } \\
\text { (сыворотка крови) }\end{array}$ & $15,2 \pm 3,9$ мкмоль/л & $0,96 \pm 0,003$ мкмоль/л \\
\hline
\end{tabular}


Таблица 4

Содержание метаболитов оксида азота в тканях кожи у людей и экспериментальных животных

\begin{tabular}{|l|c|c|c|}
\hline \multicolumn{1}{|c|}{ Группы наблюдения } & $\begin{array}{c}\mathrm{NO}_{\mathrm{x}} \\
\mu \Gamma / \Gamma\end{array}$ & $\begin{array}{c}\mathrm{NO}_{3}^{-} \\
\mu \Gamma / \Gamma\end{array}$ & $\begin{array}{c}\mathrm{NO}_{2}^{-} \\
\mu \Gamma / \Gamma\end{array}$ \\
\hline Tкань кожи человека (операционный материал) & $21,9 \pm 2,4$ & $20,1 \pm 3,1$ & $1,8 \pm 0,08$ \\
\hline Ткань гипертрофированного рубца кожи (операционный материал) & $12,6 \pm 1,8$ & $11,7 \pm 2,1$ & $0,9 \pm 0,01$ \\
\hline Ткань кожи экспериментальных крыс (нормальная) & $7,8 \pm 0,9$ & $7,4 \pm 0,2$ & $0,4 \pm 0,005$ \\
\hline Tкань кожи экспериментальных крыс (очаг воспаления) & $15,8 \pm 2,9$ & $13,7 \pm 2,4$ & $2,1 \pm 0,09$ \\
\hline
\end{tabular}

\section{ЛИТЕРАТУРА}

1. Белоус Ю.А., Комаревцева И.А., Комаревцева Е.В. Метаболизм оксида азота в почках // Вестник РУДН. Серия: Медицина. - 2008. - № 3. - С. 69-72.

2. Киселик И.О., Луциик М.Д., Шевченко Л.Ю. Особливості визначення нітратів та нітритів в периферичній крові у хворих на вірусні гепатити та при синдромі жовтяниці іншої етіології // Лабораторна діагностика. - 2001. - № 3. - С. 43-45.

3. Комаревцева E.B. Роль оксида азота и сосудистого эндотелиального фактора роста в генезе узловой тиреоидной патологии // Український медичний альманах. - 2008. - Т. 11, № 6. - С. 90-94.

4. Комаревцева И.А. Бифункциональный характер действия оксида азота в ткани почек при активации апоптоза // Український біохімічний журнал. - 2002. - Т. 74, № 4а (додаток 1). - С. 47.

5. Меньшикова Е.Б., Зенков Н.К., Реутов В.П. Оксид азота и NO-синтазы в организме млекопитающих при различных функциональных состояниях // Биохимия. - 2000. - Т. 65, Вып. 4. - С. 485-503.

6. Орлова Е.А., Комаревцева И.А. Роль NO-синтазы в стимуляции опиатных рецепторов и устойчивости почек к оксидантному стрессу // Український біохімічний. журнал. - 2004. - Т. 76, № 1. C. 97-102.

7. Forte P., Kneale B., Milne E. Evidence for a Difference in Nitric Oxide Biosynthesis Between Healthy Women and Men // Hypertension. - 1998. Vol. 32. - P. 730-734.

8. Moncada S. Nitric oxide and cell. Respiration Physiology and Patology // Verk Kon. Acad. Genelsk Belg. - 2000. - V. 62, N 3. - P. 171-179.

9. Sessa W.C., Förstermann U. Nitric oxide synthases: regulation and function // Eur. Heart J. - 2012. Vol. 33, N 7. - P. 829-837.

10. Vargas F., Moreno J.M. The endocrine system in chronic nitric oxide deficiency // Eur. J. Endocrinol. 2007. - Vol. 156. - N 1. - P. 1-12.

11. Wimalawansa S.J. Nitric oxide: new evidence for novel therapeutic indications // Expert. Opin. Pharmacother. - 2008. - Vol. 9, N 11. - P. 1935-1954.

12. Yoon Y., Song J., Ho Hong S. Plasma Nitric Oxide Concentrations and Nitric Oxide Synthase Gene Polymorphisms in Coronary Artery Disease // Clinical Chemistry. - 2000. - Vol. 46. - P. 1626-1630. 